\section{Modeling the management process in the function of long-term goal fulfillment in Croatian companies}

\section{Modeliranje procesa upravljanja u funkciji dugoročnog ispunjavanja ciljeva u hrvatskim poduzećima}

Asst. prof. Vedran Šupuković, PhD

Pan-European University Apeiron, Banja Luka

E-mail:vedran.supukovic@rk-zagreb.hr

Assoc. prof.Sanel Jakupović, PhD

Pan-European University Apeiron, Banja Luka

E-mail: sanel.e.jakupovic@apeiron-edu.eu

Assoc. prof.Ibrahim Obhođaš, $\mathrm{PhD}$

Faculty of Business Economics, International University Travnik

E-mail: ibrahim.obhodas@unvi.edu.ba

Doc. dr.sc. Vedran Šupuković

Panevropski univerzitet Apeiron, Banja Luka

E-mail:vedran.supukovic@rk-zagreb.hr

Izv. prof.dr.sc.Sanel Jakupović

Panevropski univerzitet Apeiron,

Banja Luka

E-mail: sanel.e.jakupovic@apeiron-edu.eu

Izv. prof.dr.sc. Ibrahim Obhođaš

Ekonomski fakultet, Internacionalni

univerzitet Travnik

E-mail: ibrahim.obhodas@unvi.edu.ba
Pitanje procesa upravljanja u svim organizacijama s izraženom hijerarhijskom strukturom izuzetno je složeno i jednako apstraktno kako za same sudionike, tako i za sve one koji se bave proučavanjem ove teme. Proces upravljanja uključuje odlučivanje temeljeno na odgovarajućoj ekonomskoj analizi, iskustvu, praksi, mikro i makro okruženju i sposobnosti pojedinog menadžera da stvori simbiozu zasnovanu na svim saznanjima koja će u konačnici dovesti do donošenja odgovarajuće poslovne odluke. 
Šupuković, V., Jakupović, S., Obhođaš,l.

Modeling the management process in the function of longterm goal fulfillment in Croatian companies

Cilj je ovog rada izgraditi prezentaciju modela, koji će u ovom slučaju poboljšati ekonomsku zajednicu i obogatiti svakodnevni rad poduzeća. To će omogućiti vlasničkim i upravljačkim strukturama velikog broja neadekvatno strukturiranih i interno neinstitucionaliziranih tvrtki da postanu aktivni i pasivni menadžeri svih poslovnih odnosa unutar poduzeća u kojima djeluju, umjesto aktivnih ili pasivnih promatrača.U ovom će radu biti predstavljen model upravljanja na temelju podataka istraženih kroz pet varijabli: kvaliteta ljudskih resursa, ekonomski poticaji, razvojne perspektive, upravljačke sposobnosti podređenih i zadovoljstvo poslovanjem. Jedan od ciljeva ovog rada upravo je istražiti kako te varijable utječu na zadovoljstvo poslovanja hrvatskih poduzeća. Istraživanje je provedeno na području Republike Hrvatske, u svim regijama, na reprezentativnom uzorku, dok su anketirani predstavnici poduzeća. Dobiveni odgovori analizirani su opisno, putem regresijskog modela. Dokazano je da najveći utjecaj na zadovoljstvo u poslovanju imaju menadžerski kapaciteti, gdje su beta koeficijenti 0,367 . Nešto manji utjecaj na zadovoljstvo poslovanja ima razvoj poduzeća i poticaji iz proračuna, dok najmanji utjecaj na zadovoljstvo poslovanja ima ljudski potencijal. Dobivena beta COTA statistički je značajna jer je p - vrijednost <0,05, u sva četiri slučaja. Znanstveni doprinosi ovog rada ogledaju se u modelu koji će služiti za mjerenje utjecaja zadovoljstva menadžera na temelju kvantitativnih parametara i kao primjer univerzalnog modela procjene zadovoljstva menadžera.

\section{Ključne riječi: modeli, menadžment, poduzeća, regresija, dugoročni ciljevi}

JEL klasifikacija: G34,C1

\section{Introduction}

The actual management process relates to decision-making based on appropriate economic analysis, experience, practice, micro and macro environment, and the ability of an individual manager to create a symbiosis based on all the knowledge that will ultimately lead to making an appropriate business decision. The importance of management is reflected in the following (Fisher, 2010): it improves performance, business, competitiveness, profitability and long-term value; it defines clear roles, liabilities and responsibilities; it improves decision-making processes and decision quality; it defines and implements the strategy and direction of the company; it spreads in a sustainable manner; it identifies and manages risks; it improves the essence and structure of internal control; it creates appropriate incentives in accordance with the business strategy; it attracts capital, investment and business partners; it builds reputation and trust by strengthening the relationships with stakeholders; it prepares for the generations to come.

In this context, the modeling of optimized management processes means the creation of a business platform that would render the link and interdependence of all the above mentioned, creating a framework for business decision makers to facilitate the decision-making process using a unified and collective foundation, while fostering an individual approach (Edvinsson, 2011). It is for this reason that optimization is the word that suggests the tendency to model-based improvement rather than optimum as a final solution which is in reality a more theoretical than a real derivative of a situation that is difficult or impossible to reach.

In essence, the management processes in most companies in the Republic of Croatia do not exist, or are at a very low level and predominantly based on inspiration and intuition. It is very important to emphasize that in today's modern world, an entrepreneur or manager must break through the information circle as, in spite of great availability and the Internet, it is increasingly difficult to obtain vital information that will enable timely and quality decision making (Weziak, 2007). This is why the aim of this paper is to encourage the players in the Croatian economic scene to come out of closed and strict business frameworks, since there is a need for a wider business consensus on a model that will facilitate business management and decision making. The processes taking place at the general economic level, i.e. the economies of a single region/ community/country are not individual, but are of 
a general nature, whereas they initiate the causes and consequences of a single character within a single enterprise.

In order to improve the company performance, business process management combines a managerial approach with the appropriate technology. It is a systematic approach to business advancement based on design, measurement, analysis, process improvement and management, which relies on a business approach to change management in order to improve business processes with the ultimate goal of achieving business goals, while the changes cover the entire life cycle of the process: from defining and modeling to performing, analyzing and optimizing the process (The World Bank, 2011).

The growth of the company, the organizational structure and the complexity of the management structure leads to neglect of the management-business process, leading employees to the uncertainty of the processes themselves. The consequence of this reflects in the fact of inefficiency, overcompensation of the general management process, as well as excessive administration and work intensity in the operational process itself which takes away too much time. Therefore, the establishment of a management and operational process with the focus on the implementation of the long-term goals of all hierarchical levels, i.e. the functionality of the management-operational process, is imposed as a necessity.

This is why the main intent in the management process is focused on the necessity of creating an adequate procedural organizational structure with two important determinants:

- processes,

- teams.

With the basic function of meeting the customer's needs in speed, efficiency, quick adaptation to new business conditions and market changes, there is a reduction in the restrictions between different hierarchical levels, which ultimately reduces costs. As the main role of the management and business process, there is a need for consistency in understanding all market events from requirements to customer satisfaction. Business process management involves continuous awareness of business problems, as well as the willingness to react to pos- sible errors and the introduction of products with the aim of improvement.

The problems that arise in the introduction of management-process approach are the following:

- insufficient or inadequate knowledge of the overall process, resulting in inadequate transfer of jobs between different departments and personnel in general;

- not understanding the whole process by the participants themselves, which is the key to the improvement of process.

Therefore, the management-process orientation of the organization must answer the following questions:

- How the process is modeled,

- Who does it and in what manner,

- How the efficiency of the process itself increases,

- What the bottlenecks in the processes are,

- How strategy and management are reflected on the operational process itself,

- How to optimize business processes,

- Where the weaknesses and the potential for improvement are,

- What the adequate personal resources for the implementation of the process are.

It is often the practice to introduce separate, sometimes hierarchically-institutionally isolated departments or units for identification, optimization, automation and control of business processes in the more serious corporate systems, with the ultimate goal of continuous improvement of all processes within the corporation. However, the problem of the process orientation in Croatia is mostly not of a strategic nature, but it is found in the pressure of the market environment which leads to the need to invest in a business process strategy that includes:

- Reduction of operating costs and improvement of financial flow,

- Increase in process efficiency,

- Simplifying and increasing the efficiency of business processes,

- Greater involvement of managers in the operational process itself.
Šupuković, V., Jakupović, S., Obhođaš,l.

Modeling the management process in the function of longterm goal fulfillment in Croatian companies 
Šupuković, V., Jakupović, S., Obhođaš,l.

Modeling the management process in the function of longterm goal fulfillment in Croatian companies
Determination of the required level of process maturity of an organization is a complex process and is mainly determined through a process-oriented model that establishes:

- What level of process orientation belongs to an enterprise or corporation,

- Whether the organization is characterized by the existence of defined processes,

- Whether the internal organization and systematization includes the procedural aspect,

- Whether some departments and employees adequately implement business processes, or if they are still at the level of a formal-functional nature,

- Whether the company or corporation is market-oriented.

For the purpose of efficient business process management, it is necessary to identify the business processes in the organization and their division according to the field of activity in vertical and horizontal processes. The existence of horizontal processes is a prerequisite of process orientation, and all companies that have not reached a high level of business maturity mostly organize their processes within the same organizational units.

The performance indicator of the overall organization is measured by the success of some organizational units observed as profit centers, while in those segments where it is not possible to make profitability, the performance of the organizational units is mostly monitored by the rate of realized plans over a certain period of time, which does not necessarily include only financial but also non-financial indicators.

\section{Methodology}

I In this research paper, where secondary research data were used, statistical data processing methods were used in the data analysis as follows: descriptive statistics, dynamic analysis and correlation analysis. The descriptive statistics used in this paper are reflected in the presentation of data in tabular and graphical manner, without deeper analysis. Based on the series from the previous years, the trend method predicted possible trends of certain phenomena in the future period (Paul, 2010). The data used were collected in the territory of the
Republic of Croatia, and the target group of respondents were commercial companies. One of the prerequisites for the use of regression analysis is the existence of linear dependence between variables. This is necessary since the analysis begins by calculating the simple correlation coefficients (bivariate correlations) for all pairs of variables, and all these calculations require a linear relationship between the pairs of variables.

\section{Results of the research}

\subsection{Model of the impact of human resources quality, economic incentives, development perspectives and managerial capabilities of subordinates to business satisfaction}

This model gives the best possible predictions of the dependent variable value based on the value of independent variable, if all assumptions are met. Based on the size of the regression coefficients, we can conclude how much the relative impact or importance of each independent variable is if these coefficients are converted to beta coefficients $\beta$ (Wonnacott, 1990). These coefficients are obtained when all the values of the variable are standardized. One of the prerequisites for the use of regression analysis is the existence of linear dependence between variables (World Economic Forum, 2017). This is necessary since the analysis begins with the calculation of the coefficient of simple correlation (bivariate correlations) for all pairs of variables, and all these calculations require a linear relationship between the pairs of variables.

The highest degree of correlation is present between business satisfaction and managerial capabilities of subordinates, which amounts to 0.504 , and is in a linear relationship since $p=0.000<0.05$.

The correlation coefficient, which is also in a linear relationship ( $p=0.000<0.05$ ) between business satisfaction and entrepreneurship development perspectives, is 0.478 , so we can conclude that there is a medium strong link between the two variables.

Also, there is a medium strong correlation between business satisfaction and economic incentives that amounts to 0.448 , which shows that the growth of economic incentives increases business satisfaction. The variables are in a linear relationship since 
Table 1 Model correlation

\begin{tabular}{|c|c|c|c|c|c|c|}
\hline \multicolumn{7}{|c|}{ Correlations } \\
\hline & & $\begin{array}{l}\text { Business } \\
\text { satisfac- } \\
\text { tion }\end{array}$ & $\begin{array}{c}\text { Managerial } \\
\text { capabilities } \\
\text { of suborti- } \\
\text { nates }\end{array}$ & $\begin{array}{l}\text { Entrepre- } \\
\text { neurship } \\
\text { development } \\
\text { perspectives }\end{array}$ & $\begin{array}{l}\text { Economic } \\
\text { incentives } \\
\text { from the state } \\
\text { budget }\end{array}$ & $\begin{array}{c}\text { Human } \\
\text { potential } \\
\text { available to HR }\end{array}$ \\
\hline \multirow{5}{*}{ Pear. Corr. } & Business satisfaction & 1.000 & .504 & .478 & .448 & .284 \\
\hline & $\begin{array}{l}\text { Managerial capabilities of } \\
\text { subortinates }\end{array}$ & .504 & 1.000 & .431 & .356 & .253 \\
\hline & $\begin{array}{l}\text { Entrepreneurship development } \\
\text { perspectives }\end{array}$ & .478 & .431 & 1.000 & .838 & .522 \\
\hline & $\begin{array}{l}\text { Economic incentives from the } \\
\text { state budget }\end{array}$ & .448 & .356 & .838 & 1.000 & .624 \\
\hline & $\begin{array}{l}\text { Human potential available } \\
\text { to } \mathrm{HR}\end{array}$ & .284 & .253 & .522 & .624 & 1.000 \\
\hline \multirow{5}{*}{$\begin{array}{c}\text { Sig. } \\
\text { (1-tailed) }\end{array}$} & Business satisfaction & . & .000 & .000 & .000 & .000 \\
\hline & $\begin{array}{l}\text { Managerial capabilities of } \\
\text { subortinates }\end{array}$ & .000 & . & .000 & .000 & .000 \\
\hline & $\begin{array}{l}\text { Entrepreneurship development } \\
\text { perspectives }\end{array}$ & .000 & .000 & . & .000 & .000 \\
\hline & $\begin{array}{l}\text { Economic incentives from the } \\
\text { state budget }\end{array}$ & .000 & .000 & .000 & . & .000 \\
\hline & $\begin{array}{l}\text { Human potential available } \\
\text { to HR }\end{array}$ & .000 & .000 & .000 & .000 & . \\
\hline \multirow{5}{*}{$\mathrm{N}$} & Business satisfaction & 225 & 225 & 225 & 225 & 225 \\
\hline & $\begin{array}{l}\text { Managerial capabilities of } \\
\text { subortinates }\end{array}$ & 225 & 225 & 225 & 225 & 225 \\
\hline & $\begin{array}{l}\text { Entrepreneurship development } \\
\text { perspectives }\end{array}$ & 225 & 225 & 225 & 225 & 225 \\
\hline & $\begin{array}{l}\text { Economic incentives from the } \\
\text { state budget }\end{array}$ & 225 & 225 & 225 & 225 & 225 \\
\hline & $\begin{array}{l}\text { Human potential available } \\
\text { to } \mathrm{HR}\end{array}$ & 225 & 225 & 225 & 225 & 225 \\
\hline
\end{tabular}

Source: author's processing in the statistical package SPSS 20. Data from Federalni Zavod za programiranje razvoja Bosne i Hercegovine (2017).

$p=0.000<0.05$.

There is little correlation between business satisfaction and human potential available to Croatia. Therefore, the correlation coefficient is 0.284 , so it is in a linear relationship, since $p=0.000<0.05$.

A relationship between variables can be found when analysing the model. The coefficient of determination is 0.346 , which is also representative of the model, so $34.6 \%$ of the variables are explained by this model, while some of them are unknown to us.

The custom determination coefficient is somewhat lower, amounting to 0.334 . The standard model error is significantly lower than the standard deviation $(0.72394<1.04)$, which shows that this model reduces the deviation compared to descriptive statistics. The Durbin-Watson test shows a small negative autocorrelation, which is 1.837 , and since this test value is approximately 2 , it can be conclud- ed that the degree of autocorrelation is acceptable. Quotient of the square average and the average residual yield the empirical value of the $F$ test. Based on the sample size and the empirical value of the $\mathrm{F}$ test, we obtain the significance value, which in case of multiple regression is 0.000 . The Anova test examines dependent and independent variables in order to determine the relationship between the mentioned variables.

In this case, the analysis showed that there is compatibility of dependent and independent variables, and that it is statistically significant. However, it can be concluded from the above that these variables have a high degree of dependence. Accordingly, the hypothesis set has been proven, i.e. there is a significant link between dependent and independent variables, and the determination coefficient is significant, since $p=0.000<0.05$.
Šupuković, V., Jakupović, S., Obhođaš,l.

Modeling the management process in the function of longterm goal fulfillment in Croatian companies 
Šupuković, V., Jakupović, S., Obhođaš,l.

Modeling the management process in the function of longterm goal fulfillment in Croatian companies

Table 2 A shortened model

\begin{tabular}{|c|c|c|c|c|c|c|c|c|c|c|}
\hline \multirow[b]{3}{*}{ Model } & & & & & idel Summa & & & & & \\
\hline & \multirow[b]{2}{*}{$R$} & \multirow[b]{2}{*}{ R Square } & \multirow{2}{*}{$\begin{array}{l}\text { Adjusted } \\
\text { R Square }\end{array}$} & \multirow{2}{*}{$\begin{array}{l}\text { Std. Error } \\
\text { of the } \\
\text { Estimate }\end{array}$} & \multicolumn{5}{|c|}{ Change Statistics } & \multirow{2}{*}{$\begin{array}{l}\text { Durbin- } \\
\text { Watson }\end{array}$} \\
\hline & & & & & $\begin{array}{l}\text { R Square } \\
\text { Change }\end{array}$ & F Change & df1 & $\mathrm{df} 2$ & $\begin{array}{l}\text { Sig.F } \\
\text { Change }\end{array}$ & \\
\hline 1 & $.588 a$ & .346 & .334 & .72394 & .346 & 29.070 & 4 & 220 & .000 & 1.837 \\
\hline \multicolumn{11}{|c|}{$\begin{array}{l}\text { a. Predictors: (Constant), Human potential available to HR, Managerial capabilities of subordinates, Entrepreneurship develop- } \\
\text { ment perspectives, Economic incentives from the state budget }\end{array}$} \\
\hline
\end{tabular}

Source: author's processing in the statistical package SPSS 20.

Table 3 The ANOVA test

\begin{tabular}{|c|c|c|c|c|c|c|}
\hline \multicolumn{7}{|c|}{ ANOVA $^{a}$} \\
\hline \multicolumn{2}{|c|}{ Model } & Sum of Squares & $\mathrm{df}$ & Mean Square & $\mathrm{F}$ & Sig. \\
\hline 1 & Regression & 60.941 & 4 & 15.235 & 29.070 & $.000^{\mathrm{b}}$ \\
\hline & Residual & 115.299 & 220 & .524 & & \\
\hline & Total & 176.240 & 224 & & & \\
\hline & endent variab & e: Business satisfa & & & & \\
\hline
\end{tabular}

Source: author's processing in the statistical package SPSS 20.

Table 4 Beta coefficients

\begin{tabular}{|c|c|c|c|c|c|c|c|c|}
\hline \multicolumn{9}{|c|}{ Coefficients ${ }^{\mathrm{a}}$} \\
\hline & \multirow{2}{*}{ Model } & \multicolumn{2}{|c|}{$\begin{array}{l}\text { Unstandardized } \\
\text { Coefficients }\end{array}$} & \multirow{2}{*}{$\begin{array}{l}\text { Standard- } \\
\text { ized Coeffi- } \\
\text { cients } \\
\text { Beta }\end{array}$} & \multirow{2}{*}{$\mathrm{t}$} & \multirow{2}{*}{ Sig. } & \multicolumn{2}{|c|}{ Collinearity Statistics } \\
\hline & & B & Std. Error & & & & Tolerance & VIF \\
\hline \multirow{6}{*}{1} & (Constant) & .363 & .204 & & 5.711 & .000 & & \\
\hline & $\begin{array}{l}\text { Managerial } \\
\text { capabilities of } \\
\text { subortinates }\end{array}$ & .149 & .060 & .367 & 6.064 & .000 & .812 & 1.231 \\
\hline & $\begin{array}{l}\text { Entrepreneurship } \\
\text { development } \\
\text { perspectives }\end{array}$ & .150 & .086 & .180 & 1.744 & .043 & .278 & 3.600 \\
\hline & $\begin{array}{l}\text { Economic incen- } \\
\text { tives from the } \\
\text { state budget }\end{array}$ & -.010 & .094 & .174 & 1.597 & .049 & .250 & 3.997 \\
\hline & $\begin{array}{l}\text { Human potential } \\
\text { available to HR }\end{array}$ & & .061 & -.012 & -169 & .866 & .610 & 1.640 \\
\hline & a. Dependent varia & Busin & satisfact & & & & & \\
\hline
\end{tabular}

Source: author's processing in the statistical package SPSS 20.

Based on the obtained beta coefficient, it can be concluded that managerial capabilities of subordinates have the greatest impact on business satisfaction, since the beta coefficient is 0.367 . This coefficient is also significant since the tested value is lower than 0.05 .

Further, in case of entrepreneurship development perspectives, the beta coefficient is 0.180 , and it is also statistically significant, since the tested value is 0.043 , which is less than 0.05 .

Economic incentives from the state budget have somewhat lower impact on business satisfaction, in this case the beta coefficient is 0.174 , and it is also statistically significant, since $p=0.049<0.05$. 
Table 5 Heteroscedasticity

\begin{tabular}{|l|l|l|}
\hline Test & LM & Sig. \\
\hline B - P test & 43,126 & 0,000 \\
\hline
\end{tabular}

Source: author's processing in the statistical package SPSS.

Figure 1 Normality test

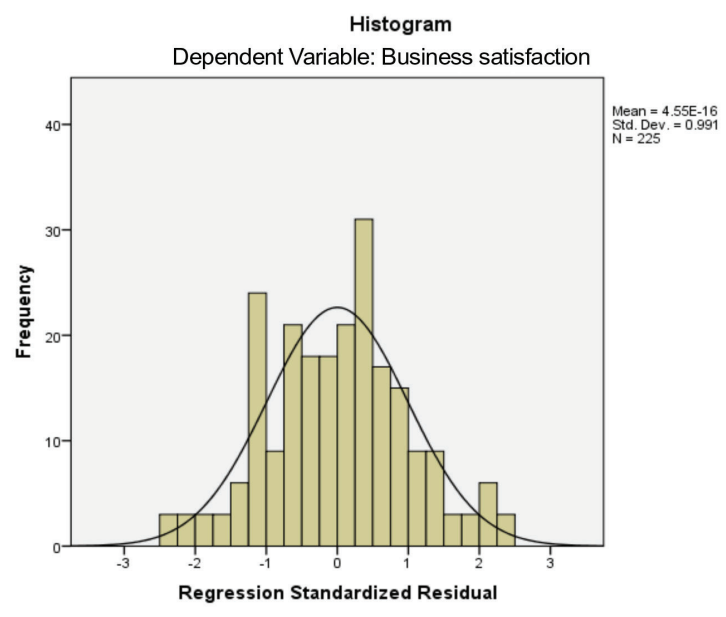

Source: author's processing in the statistical package SPSS 20.

Figure 2 Linearity test

Normal P-P Plot of Regression Standardized Residual

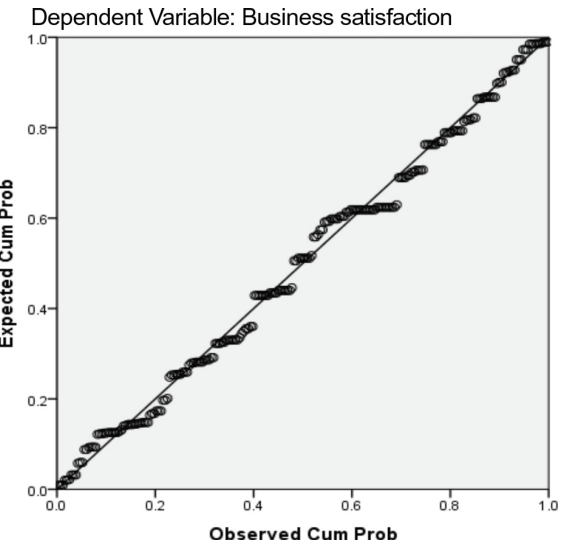

Source: author's processing in the statistical package SPSS 20. 
Šupuković, V., Jakupović, S., Obhođaš,l.

Modeling the management process in the function of longterm goal fulfillment in Croatian companies
The data analysis, i.e. the model, shows that the human potentials available to Croatia have a negative beta coefficient on employee satisfaction, however, the obtained coefficient is not statistically significant, since $p=0.866>0.05$, so it cannot be taken as relevant and accurate information.

The Breusch-Pagan test of heteroskedasticity is not present if Sig. value is less than 0.05, which means it rejects our hypothesis. It can be concluded from the analysis that $p=0.000<0.05$, so we may deduce that the tested model is normally distributed.

This can also be seen on the following graphs, as the model is normally distributed, and it is a model that follows a linearly rising movement.

The Business Satisfaction histogram shows that the analyzed model is normally distributed, which previous analyses have shown.

The analyzed model is in linear relationship, which is shown in the previous tables through the necessary analyses.

\section{Conclusion}

Management is an important segment of every business organization, and in addition to making decisions based on qualitative data, quantitative data have been increasingly used in practice. In order to reach quality conclusions, a certain analysis needs to be done. One of these analyses is certainly modeling using the regression method. Based on the analysis made, as well as modeling with a special emphasis on business satisfaction, the conclusion arises that the most important variable is the variable that has the greatest impact, which is managerial capability. In addition, a variable that also has a significant impact on business satisfaction is the economic incentive, which is unfortunately at a poor level, at least according to the conclusions and responses provided by business entities. This analysis also included the measurement of human potentials for business satisfaction, as well as the perspectives of entrepreneurship in the Republic of Croatia. Modeling is an important factor in business management. In addition to the analysis that arises from the primary research processes, it is also important to mention the modeling based on secondary data or time series. It is possible to make a certain connection between the variables within the company, and the results of the analysis should be guidelines in reducing costs, making investment decisions, risk assessment, etc. It is important to emphasize that each model has its representativity or likelihood of achievement, so that the obtained results are taken with greater or less emphasis in the final realization. Each model implies the creation of numerous tests that give greater or lesser emphasis to the obtained results of the research. An example of a conducted model gives clear guidelines to which parameters it is not necessary to pay the utmost attention, and which have the greatest impact on business satisfaction. The model is not finished after the results are obtained, therefore it is necessary to invest certain resources according to the obtained results, if the goal is to improve the dependent variable of the model. The disadvantage of this research is the insufficient number of variables that definitely affect business satisfaction, which are not covered by this research, due to the lack of data. A measurable impact on business satisfaction would add additional quality to the model, making it complete and complete.The recommendation for the next research is to explore all those elements that affect business satisfaction, design and do research, design variables and introduce a new model. The model would include a number of variables, where those with the highest degree of influence on the dependent variable would be extracted through factorial analysis. 


\section{References}

Lin, C. Y. Y., Edvinsson, L. (2011) National intellectual capital: A comparison of 40 countries. New York, NY: Springer New York.

Federalni Zavod za programiranje razvoja Bosne i Hercegovine (2017) Konkurentnost 2017-2018 Bosna i Hercegovina. Sarajevo: Federalni Zavod za programiranje razvoja Bosne i Hercegovine.Available at: http:// www.fzzpr.gov.ba/bs/pubs/32/8/konkurentnost-bosne-i-hercegovine [8.10.2019].

Fisher,J.(2010) Corporate Governance and Management of Risk. Best managament practice.Axelos White Paper. UnconfuseU Ltd. London.

Paul,N.W.(2010) Statistika za poslovanje i ekonomiju.Zagreb: Mate Zagreb.

The World Bank (2011) The Changing Wealth of Nations: Measuring Sustainable Development in the New Millennium. The World Bank.

Weziak, D. (2007) Measurement of National Intellectual Capital: Application to EU Countries. IRISS Working Paper Series. Instead.

Wonnacott, T. W. (1990) Introductory Statistics for Business and Economics. New York: Wiley New York. World Economic Forum (2017) The Global Competitiveness Report. Geneva: World Economic Forum. 
